原

\title{
ヒト歯根膜細胞中に存在する アルカリフォスファターゼ陽性細胞と陰性細胞の特徵
}

\author{
鶴見亜有子，小 林 誠，村山怜一郎，臼井 通彦 \\ 小出 容子，山本 松男
}

要旨：歯根膜組織中には，セメント質や歯槽骨などの硬組織を形成する骨芽細胞様細胞と，腱や䩲帯と類 似した構造・機能を有する歯根膜線維を形成する線維芽細胞様細胞が存在すると考えられているが, これら を識別・分取することが可能な特徵的なマーカー分子は明らかにされていない。そこで本研究では，骨マー カーである alkaline phosphatase (ALP) を指標として，へテロな培養ヒト歯根膜細胞（HPL cells）から フローサイトメトリーで蛍光（allophycocyanin）強度が著しく強い ALP 陽性の細胞集団 $[$ ALP $(+)$ HPL cells] と蛍光強度が著しく弱い ALP 陰性の細胞集団 [ALP ( - ) HPL cells] を分取し，これら 2 つの細胞 集団の特徵, 特に細胞増殖能, 骨芽細胞様分化能および，コラーゲン線維の形成，骨形成，骨芽細胞分化・ 石灰化への関与が指摘されている Biglycan と Decorinの発現を比較検討した。その結果，ALP $(+)$ HPL cells を骨分化誘導培地 (ODM) で培養すると明確な ALP 活性の上昇と石灰化の誘導ならびに骨マーカー遺 伝子 (ALP, osterix, osteopontin) 発現の増加が認められたことから，この細胞集団は骨芽細胞様の細胞集団 であり，一方，ALP (-) HPL cells は細胞増殖能が高く，骨芽細胞様の分化能が乏しい線維芽細胞様の細胞 集団であることが明らかになった。また，Biglycan は ALP $(+)$ HPL cells で，Decorin は ALP $(-)$ HPL cells でより強く発現しており, 精製ヒト Biglycan は特に ALP $(+)$ HPL cells において ODM が誘導する骨 芽細胞様分化を有意に㠵進した。さらに，両細胞集団を ODM で培養すると，Decorinの発現は促進された が，Biglycanの発現は変化しなかった。したがって，Biglycan は特に ALP $(+$ ) HPL cells における骨芽細 胞様分化を促進的に制御しており，一方 Decorin は骨芽細胞様分化の誘導過程で発現が増加し，両細胞集団 における石灰化を抑制的に制御していると考えられる。

歯根膜は歯槽骨とセメント質を繫ぐ線維性結合組織で あるが，この組織中には硬組織形成細胞（骨芽細胞，セ メント芽細胞), 線維芽細胞, 血管構成細胞, 神経細胞, これら細胞種の前駆細胞やさらに未分化な組織幹細胞 ${ }^{1)}$ など，分化の程度が異なる多種の細胞が存在していると 考えられている. また, 過去報告された多くのin vivoの 研究結果は, 歯の支持組織, 特に歯根膜の再生には既存 の歯根膜の存在が不可欠であることを示している2,3).し たがって，歯根膜組織中に存在する種々の細胞は歯の支 持組織の再生や恒常性の維持において重要な役割を演じ ている可能性がある。

過去の研究から，へテロな細胞集団である培養歯根膜 細胞中には骨芽細胞様の特徵を有する細胞が存在するこ とが明らかにされており ${ }^{4 \sim 7)}$, この骨芽細胞様細胞は歯の 支持組織のうち，歯槽骨やセメント質といった硬組織の 再生や恒常性の維持に関わると考えられている。一方, 歯根膜組織は，主として腱・䨣帯と類似した構造・機能
を有する歯根膜線維で構成されている。したがって, こ の組織中には歯根膜線維の再生や恒常性の維持を担う線 維芽細胞が存在していると考えられるが，その特徵やこ の細胞を識別・分取することが可能な特異的な細胞表層 分子は明確でない。

歯根膜組織中には主要な骨マーカーである alkaline phosphatase (ALP) の陽性細胞と陰性細胞が存在し ており，培養歯根膜細胞から磁気ビーズ法で分取した ALP 陽性細胞は ALP 陰性細胞と比較して, 骨芽細胞様 の分化能が高いこと委，また Fibroblast growth factor (FGF), Transforming growth factor- $\beta$ (TGF- $\beta$ ) の 受容体や骨マーカーである osteocalcin と bone sialoprotein の遺伝子発現が強く, basic FGF 依存的な細胞 増殖能が高いこと ${ }^{9)}$ が報告されている. しかし, 培養歯 根膜細胞中に存在する ALP 陽性細胞と ALP 陰性細胞 の特徴は未だ不明な点が多い。

一方，歯根膜組織中には骨芽細胞様の細胞が存在して 
いるにもかかわらず，この組織は石灰化することなく組 織の恒常性が維持されている。したがって, 主要な歯根 膜構成細胞である骨芽細胞様細胞と線維芽細胞様細胞 は，自らの骨芽細胞様分化や石灰化を制御する分子を産 生している可能性がある. Class 1 small leucine rich proteoglycan (SLRP) に属する細胞外基質タンパク質 (ECM) である Biglycan と Decorin は, 腱, 䩲帯や歯 根膜での発現が確認されており ${ }^{10 \sim 12) ， ま た ， こ の よ う な ~}$ 細胞機能の調節に関わる候補分子であると考えられる。 実際, Biglycan と Decorin は骨芽細胞の分化過程で発 現が上昇し，ともに石灰化に関与しているが，Biglycan は骨形成や骨芽細胞の増殖・分化・活性・石灰化を促進 的に制御するのに対し, Decorin は骨形成や骨芽細胞の 増殖・分化に影響せず，むしろ石灰化を抑制的に制御す ると報告されている ${ }^{13 \sim 15)}$. しかし, 培養歯根膜細胞中に 存在する ALP 陽性細胞とALP 陰性細胞における, Biglycan と Decorin の発現, 骨芽細胞様分化の誘導に伴う これらの分子の発現動態, これらの分子が骨芽細胞様分 化に及ぼす作用に関する報告はない。

そこで本研究では, 培養ヒト歯根膜細胞 (Human Periodontal Ligament cells: HPL cells) からフローサ イトメトリーでALP 陽性の細胞集団とALP 陰性の細 胞集団を分取し，これら 2 つの細胞集団の特徵，特に細 胞増殖能, 骨芽細胞様分化能および Biglycan と Decorin の発現を比較検討した。

\section{材料と方法}

\section{HPL cells $の$ 採取}

昭和大学歯学部医の倫理委員会の規定に基づき研究へ の参加の同意が得られ，歯周病に罹患していない 5 人の 患者の歯科治療上の必要性で抜去された歯から，それぞ れ HPL cells を得た. HPL cells は, 各抜去歯根の中央 $1 / 3$ の部位から採取した歯根膜片から， $0.2 \%$ コラゲナー ゼ (Wako Pure Chemical Industries, Ltd., Osaka, Japan) 含有 Minimum essential medium $\alpha$ (MEM $\alpha$; Wako）を使用し， $37^{\circ} \mathrm{C}, 20$ 分間の処理を 3 回繰り返す ことにより採取した（HPL-1, -2, -3, -4, -5 cells).また, 実験には, 2, 3 回目の酵素処理で採取した細胞を用いた。

\section{2. $\mathrm{ALP}(+)$ HPL cells と $\mathrm{ALP}(-)$ HPL cells の分取}

採取した各 HPL cells 10\%ウシ胎児血清（FBS; GIBCO, Grand Island, NY, USA), ペニシリン (100 units $/ \mathrm{ml})$ ，ストレプトマイシン $(100 \mu \mathrm{g} / \mathrm{ml})$ を含む $\mathrm{MEM} \alpha$ 中に懸濁し, $37^{\circ} \mathrm{C}, 95 \%$ air $/ 5 \% \mathrm{CO}_{2}$ の環境下 で継代培養した。コンフルエントに達した 2 代目の細胞 をさらに 3 日間培養した後, 細胞層をセルスクレーパー
で回収した。回収した細胞層を Cell dissociation buffer (Invitrogen Corp., Carlsbad, CA, USA) に 30 分間懸濁 後, $2000 \mathrm{rpm}(400 \times g), 4^{\circ} \mathrm{C}$ で 3 分間遠心し, 上清を除 去後, 細胞数を測定した。 $4 \times 10^{6}$ 個の細胞を $1 \mathrm{ml}$ の Phosphate-buffered saline (PBS; Takara Bio Inc., Siga, Japan）中に懸濁した後，水上で， $25 \mu \mathrm{g} / \mathrm{ml}$ の allophycocyanin (APC) 標識抗ヒト/マウス/ラット ALP モノクローナル抗体（R＆D Systems, Minneapolis, MN, USA) を $10 \mu 1 / 1 \times 10^{5}$ cells の割合で添加 し, 30 分間処理した. 反応後, $2000 \mathrm{rpm}(400 \times g), 4^{\circ} \mathrm{C}$ で 3 分間遠心し, 上清を除去後, 細胞を $1 \mathrm{ml}$ の PBS に 再懸濁したのち, 死細胞を区別するために $2 \mu 1$ の Propedium iodide (PI) を加え, これをフローサイトメトリー 解析および細胞分取用のサンプルとした。解析および細 胞分取は Fluoresence-activated cell sorting (FACS) VantageSE $^{\circledR}$ (Becton Dickinson, Franklin Lakes, NJ, USA）を使用して行った。 各サンプル中のPI 陰性の生 細胞から, 蛍光強度が著しく強い（APC 蛍光強度 100 以上）ALP 陽性の細胞分画 $[\mathrm{ALP}(+) \mathrm{HPL}$ cells $]$ と 蛍光強度が著しく弱い（APC 蛍光強度 2 以下）ALP 陰 性の細胞分画 [ALP (-) HPL cells] の細胞集団を分 取した.デー夕解析には FlowJo (Tree Star Inc., Ashland, Oregon, USA）を用いた。

\section{3. 細胞数の測定}

細胞増殖能を調べるために, ALP $(+)$ HPL cells と ALP (一) HPL cells それぞれを，24穴プレートに $1 \times$ $10^{4}$ 個/穴の割合で播種し, 間葉系幹細胞増殖培地 (MSCGM; Lonza, Walkersville, MD, USA) で 1，3， 5,7 日間培養後, 血球計算板を用いて細胞数の測定を行 った。

\section{4. 骨分化誘導}

$\mathrm{ALP}(+)$ HPL cells と ALP $(-)$ HPL cells それぞれ を, 96 穴, 24 穴, 6 穴プレートにそれぞれ $5 \times 10^{3}, 2 \times 10^{4}$, $1 \times 10^{5}$ 個/穴ずつ播種し，MSCGM でコンフルエントに 達するまで培養後, さらに精製ヒト Biglycan $(0.1,1,5$ $\mu \mathrm{g} / \mathrm{ml}$; R \& D Systems) の存在あるいは非存在下におい て，骨分化誘導培地（ODM; Lonza）あるいはコントロ ール培地 (MSCGM) で3，7 日間培養した。

\section{Alkaline phosphatase (ALP) 活性}

細胞を $0.1 \%$ Triton X-100 含有 $50 \mathrm{mM}$ Tris- $\mathrm{HCl}$ 緩 衝液（pH 7.4）中で超音波処理にて粉砕後, 基質液 [pnitrophenyl phosphate, $0.05 \mathrm{M}$ sodium carbonate, 2 $\mathrm{mM} \mathrm{MgCl} 2\left(\mathrm{pH} \mathrm{10.0)}\right.$ ] を加え, $37^{\circ} \mathrm{C}$ で 15 分間反応させ た. 酵素活性として p-nitrophenol の遊離量を，405 nm の吸光度で測定した. タンパク量の測定は Bradford 法 ${ }^{16)}$ で行った。また，一部の細胞を 95\% methanol で 
15 分間固定後, TRACP \& ALP double-stain Kit （Takara）を用いて ALP 活性染色を行った。

\section{6. 石灰化}

細胞を 95\% methanol で 15 分間固定後, $2 \%$ alizarin red S（pH 4.2）で染色し，石灰結節の形成を確認した。 また，石灰化は，細胞層に結合した alizarin red を 10\% cetylpyridium chloride で溶解後，その遊離量を $570 \mathrm{~nm}$ の吸光度で測定することにより評価した。

\section{RT-PCR}

細胞を RNeasy Mini Kit (Qiagen, Valencia, CA, USA）中の Buffer RLT で回収後，RNeasy Mini Kit (Qiagen）を用いて全 RNA を抽出した。cDNA は，全 RNA $(2 \mu \mathrm{g})$ から逆転写酵素（M-MLV; Invitorogen） 1 $\mu 1,5 \times$ first standard buffer (Invitorogen) $4 \mu 1$, d-NTP (2.5 mM) (Takara) $4 \mu \mathrm{l}$, DTT (0.1 M) (Invitorogen) $2 \mu \mathrm{l}, \mathrm{DEPC}$ water $0.8 \mu \mathrm{l}$ とランダムプライマー (500 ng/ $\mu 1$ ) (Takara) $0.2 \mu 1$ を用いて合成した。cDNA 合成 後, $20 \mu 1$ の混合液 [cDNA $1 \mu$ l, PCR buffer (Platinum PCR Super Mix; Invitrogen) $17 \mu$, 特異的 sense/ antisense プライマー $1 \mu 1$ ] で遺伝子の増幅を行った。 使用した PCR プライマーと PCR 条件を以下に示す。

PCR プライマー;

ALP: 5'-GTACTGGCGAGACCAAGCG-3', 5’-GGCCCAGCGCAGGATGGAGG-3' (382 bp, Accession No.: AB011406), Osteopontin: 5'-GCATCACCTGTGCCATACC-3'， 5'-CATTCAACTCCTCGCTTTCC-3' $\quad$ (522 bp, Accession No.: J04765), Osterix: 5'-CCTGGCTGCGGCAAGGTGT-3', 5'-GATCTCCAGCAAGTTGCTCTGC-3' (398 bp) ${ }^{17)}$, Decorin: 5'-TGATTGTCATAGAACTGGGCACC-3', 5' -CGGGTTGCTGAAAAGACTCACAC-3' (472 bp) ${ }^{18)}$, Biglycan: 5'-ATCAGCCTCTTCAACAACCCCGTG-3'， 5'-GCCCACTGTCCCCATTCTTATG-3' (492bp) ${ }^{18)}$, GAPDH: 5' -ACCACAGTCCATGCCATCAC-3， 5'-TCCACCACCCTGTTGCTGTA-3' (452 bp) ${ }^{19)}$.

PCR 条件；

ALP: $94^{\circ} \mathrm{C} 2$ 分間, 30 cycles $\left(94^{\circ} \mathrm{C} 45\right.$ 秒間, $60^{\circ} \mathrm{C} 45$ 秒 間, $72^{\circ} \mathrm{C} 60$ 秒間), Osteopontin: $94^{\circ} \mathrm{C} 2$ 分間, 32 cycles $\left(94^{\circ} \mathrm{C} 45\right.$ 秒間, $60^{\circ} \mathrm{C} 45$ 秒間, $72^{\circ} \mathrm{C} 60$ 秒間), Osterix: $94^{\circ} \mathrm{C} 2$ 分間, 35 cycles $\left(94^{\circ} \mathrm{C} 30\right.$ 秒間, $60^{\circ} \mathrm{C} 30$ 秒間, $72^{\circ} \mathrm{C}$ 30 秒間), Decorin: $94^{\circ} \mathrm{C} 60$ 秒間, 22 cycles $\left(94^{\circ} \mathrm{C} 60\right.$ 秒 間， $60^{\circ} \mathrm{C} 60$ 秒間， $72^{\circ} \mathrm{C} 60$ 秒間)，Biglycan: $94^{\circ} \mathrm{C} 60$ 秒 間， 30 cycles $\left(94^{\circ} \mathrm{C} 60\right.$ 秒間， $60^{\circ} \mathrm{C} 60$ 秒間， $72^{\circ} \mathrm{C} 60$ 秒 間), GAPDH: $94^{\circ} \mathrm{C} 4$ 分間, 22 cycles $\left(92^{\circ} \mathrm{C} 60\right.$ 秒間, $59^{\circ} \mathrm{C}$ 30 秒間， $72^{\circ} \mathrm{C} 90$ 秒間)。

RT-PCR 産物はエチジウムブロマイド含有 $2 \%$ アガロ
ースゲルで電気泳動後, ChemiDoc XRS （Bio-Rad Laboratories Inc., Hercules, CA, USA）で紫外線照射 下にてバンドを検出し，Quantity One（Bio-Rad）を用 いて半定量解析を行った。

\section{8. ウエスタンブロット分析}

細胞を PBS で洗浄後, 1\% Triton X-100 と 1\%プロテ アーゼインヒビターカクテル (Sigma Chemical Co., St. Louise, MO, USA) を含む Tris- $\mathrm{HCl}$ 緩衝液 [25 mM Tris- $\mathrm{HCl}$ (pH 7.5), 150 mM NaCl] 中で可溶化した。サ ンプル (20 $\mu \mathrm{g} /$ lane) を 8\% SDS-ポリアクリルアミドゲ ルで電気泳動後, PVDF メンブレン (Bio-Rad)にセミド ライブロッター (MilliBlot-SDE system; Millipore Co., Bedford, MA, USA）を用いて転写した。メンブレンは ブロッキング溶液 [10 mM Tris-HCl（pH 7.2), 150 mM $\mathrm{NaCl}, 5 \%$ (w/v) スキムミルク，0.1\% (v/v) Tween 20] で 1 時間ブロッキングし，抗ヒト Biglycan ヤギポリク ローナル抗体（200 倍希釈；Santa Cruz Biotechnology, Inc., Santa Cruz, CA, USA) あるいは抗ヒト Decorin ヤ ギポリクローナル抗体 (200 倍希釈 ; Santa Cruz)を 1 次 抗体として, 室温で 1 時間反応させた後, HRP 標識抗ヤ ギ IgG (10000 倍希釈; Santa Cruz) を 2 次抗体として, 室温で 1 時間反応させた。 また，タンパク質の検出には ECL plus (GE Healthcare UK Ltd. Amersham Place, Buckinghamshire, UK) を用いた。

\section{9. 統計処理}

全ての実験は各 HPL cells から分取した $\operatorname{ALP}(+)$ HPL cells と ALP $(-)$ HPL cells それぞれで 3 回ずつ 行った. 統計分析は one-way ANOVA と Post hoc $\mathrm{t}$ 検 定で行った。

\section{結果}

\section{1. $\mathrm{ALP}(+)$ HPL cells と $\mathrm{ALP}(-)$ HPL cells の 分取}

2 代目の 5 つの HPL cells (HPL-1, -2, -3, -4, -5 cells) それぞれを MEM $\alpha$ でコンフルエントに達するまで培 養したのち，さらに 3 日間培養した。その後，それぞれ $4 \times 10^{6}$ 個の細胞を APC 標識抗ヒト ALP 抗体で染色し, FACS 解析を行った。その結果，解析を行った細胞中の ALP 陽性細胞率は平均 $70.74 \%, A L P$ 陰性細胞率は平 均 29.26\%であった (Figure 1).さらに, 各 HPL cells から, 蛍光強度が著しく強い（APC 蛍光強度 100 以上） ALP 陽性の細胞分画 $[\mathrm{ALP}(+)$ HPL cells $]$ と蛍光強 度が著しく弱い（APC 蛍光強度 2 以下）ALP 陰性の細 胞分画 $[\mathrm{ALP}($ - ) HPL cells $]$ を分取したところ, $\operatorname{ALP}(+)$ HPL cells の割合は平均 $6.28 \%, \operatorname{ALP}(-)$ HPL cells の割合は平均 5.55\%であった（Fig. 1). 


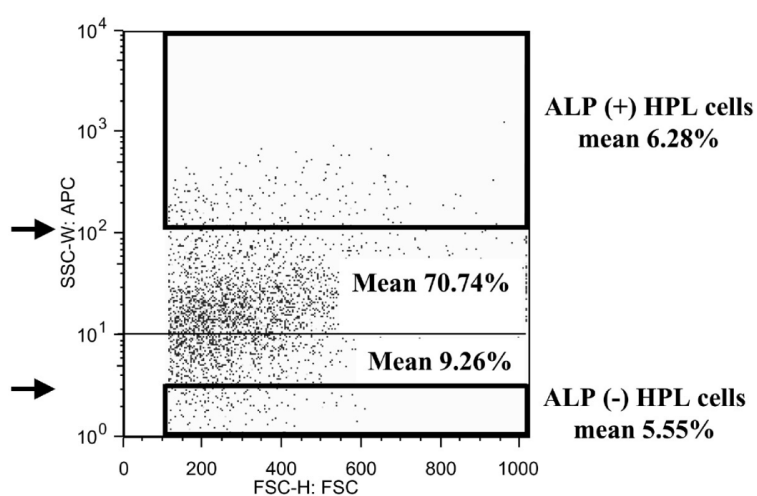

Fig. 1 Isolation of $\operatorname{ALP}(+)$ and $\operatorname{ALP}(-)$ subsets from cultured human periodontal ligament (HPL) cells. Five populations of HPL cells (HPL-1, -2, - -3, - -4 and -5 cells) at confluence were respectively cultured for 3 days with MEM $\alpha$ with $10 \%$ FBS. Then, each cell population $(4 \times$ $10^{6}$ cells) was stained with allophycocyanin-labeled monoclonal antibodies for ALP for $30 \mathrm{~min}$ on ice, and then used for flowcytometric analysis. ALP $(+)$ HPL cells and ALP $(-)$ HPL cells were separately collected from indicated fractions.

\section{2. 細胞増殖能}

HPL-1，-2，-3 cells から分取した両細胞集団を MSCGM で 1，3，5，7 日間培養後, 細胞数をカウント した. ALP $(+)$ HPL cells は培養開始 5 日後まで, ALP (一) HPL cells は培養開始 7 日後まで, 時間依存 的に細胞数の増加が認められたが，3 日後以降では, $\operatorname{ALP}(+) \mathrm{HPL}$ cells と比較して ALP $(-)$ HPL cells で 胞数が多く, 7 日後では有意な差が認められた (Fig. 2)。

\section{3. 骨芽細胞様分化能}

HPL-1，-2，-3 cells から分取した両細胞集団を MSCGM でコンフルエントに達するまで培養すると (Day 0), ALP $(+)$ HPL cells $\operatorname{ALP}(-)$ HPL cells と比較して有意に高い ALP 活性を示していた（Figure 3A，3B)。これら二つの細胞集団における ALP 活性值 は，分取後 2 代継代した細胞 (4 代目) でも変化しなかっ た (data not shown)。また，両細胞集団をさらに ODM で 3 日間培養すると，コントロール培地で培養した場合 と比較して ALP 活性の有意な増加が認められたが，そ の活性值は $\operatorname{ALP}(+)$ HPL cells と比較して $\operatorname{ALP}(-)$ HPL cells で有意に低かった（Fig. 3A, 3B).

ODM で培養開始 7 日後において, $\operatorname{ALP}(+) \mathrm{HPL}$ cells では, コントロール培地で培養した場合と比較して 著しい石灰化結節の形成と有意な細胞層中の alizarin

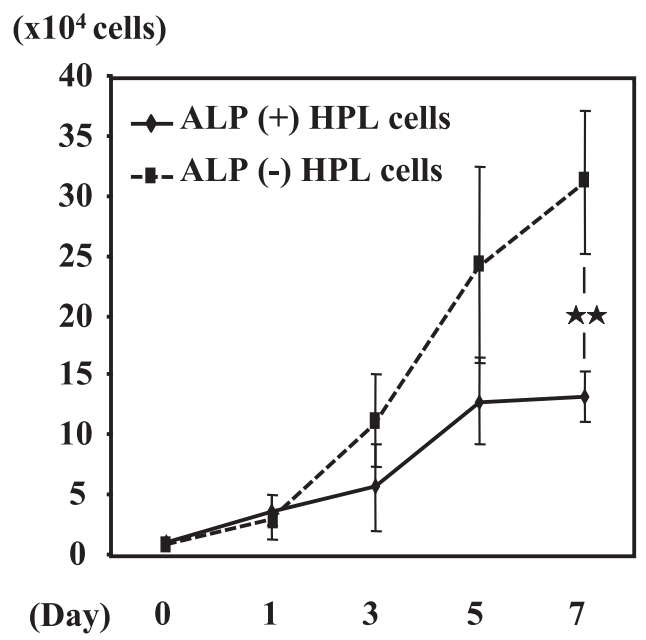

Fig. 2 Mitogenic activity in ALP $(+)$ HPL cells and ALP $(-)$ HPL cells. ALP $(+)$ HPL cells and $\mathrm{ALP}(-)$ HPL cells $\left(1 \times 10^{4}\right.$ cells/well) were respectively cultured with mesenchymal stem cell growth medium (MSCGM) for 1, 3, 5 and 7 days, and then number of cells was counted. Each value is shown as the mean $\pm \mathrm{SD}$ of 3 separate experiments for each subset isolated from each of 3 populations of HPL cells (HPL-1, -2 and -3 cells) $(n=9)$. Differences from the values for $\operatorname{ALP}(+)$ cells were considered to be significant at $\mathrm{p}<0.01(\star \star)$.

red 量の増加が認められた。一方, ODM で培養した $\operatorname{ALP}(-)$ HPL cells における石灰化結節の形成と alizarin red 量の増加は極めて微弱であり, その alizarin red 量は ALP $(+)$ HPL cells と比較して有意に少なか った (Fig. 3A, 3B).

また，両細胞集団をODM で 7 日間培養すると， $\operatorname{ALP}(+)$ HPL cells と比較して ALP $(-)$ HPL cells で 種々の骨マーカー遺伝子 (ALP, osterix, osteopontin) の 発現が有意に弱いことが確認された (Fig. 3C).

\section{Decorin と Biglycan の発現}

HPL-3，-4，-5 cells から分取した両細胞集団を MSCGM でコンフルエントに達するまで培養後, Decorin Biglycanの発現を遺伝子レベルで確認したと ころ, Decorinの遺伝子発現は $\operatorname{ALP}(-)$ HPL cells で,一方, Biglycanの遺伝子発現はALP $(+)$ HPL cellsで有意に強いことが明らかになった (Fig. 4A). また，HPL-3 cells から分取した ALP $(+)$ HPL cells と ALP (一) HPL cells のみならず (Fig. 4B), HPL-4, -5 cells から分取した両細胞集団において（data not 
A
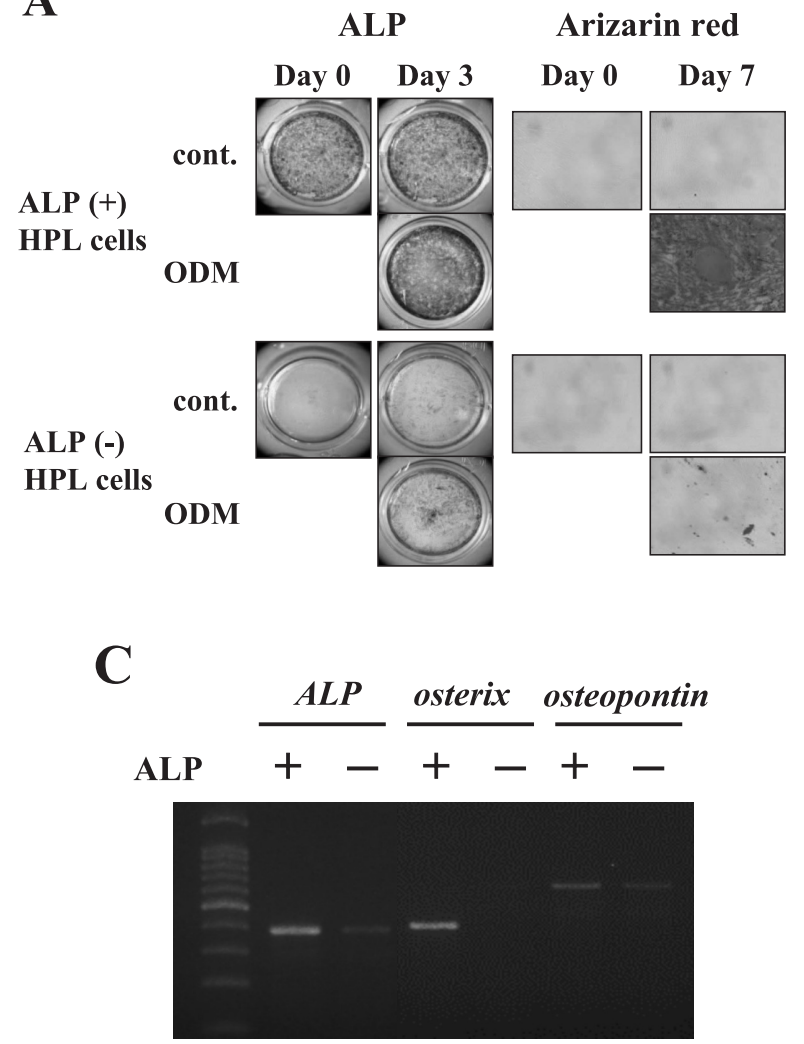

(1)

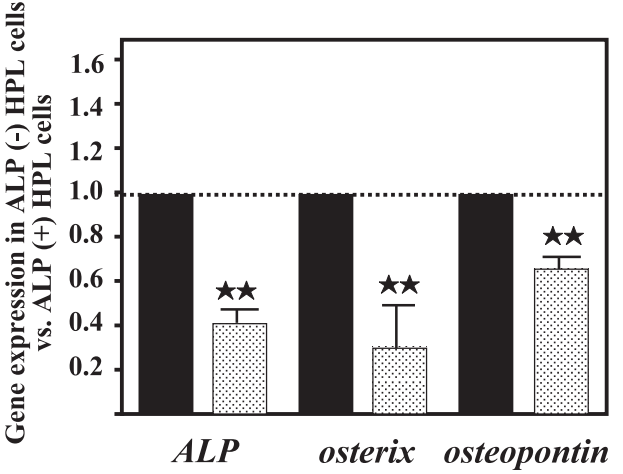

shown), 同様の結果がタンパク質レベルで確認された。

5. 骨芽細胞様分化の誘導に伴う Decorin と Biglycan の遺伝子発現の変化

HPL-3，-4，-5 cells から分取した両細胞集団を MSCGM でコンフルエントに達するまで培養後, さらに ODM あるいはコントロール培地で 3,7 日間培養した 後, Decorin と Biglycan の遺伝子発現を確認した.ODM で培養すると, $\operatorname{ALP}(+)$ HPL cells と ALP $(-)$ HPL cells ともに, Decorin の遺伝子発現はコントロール培地 で培養した場合と比較して, 培養開始 3,7 日後で有意に 増加したが, Biglycan の遺伝子発現は, 培養期間を通し て有意な変化は認められなかった（Fig. 5A, 5B)。
B
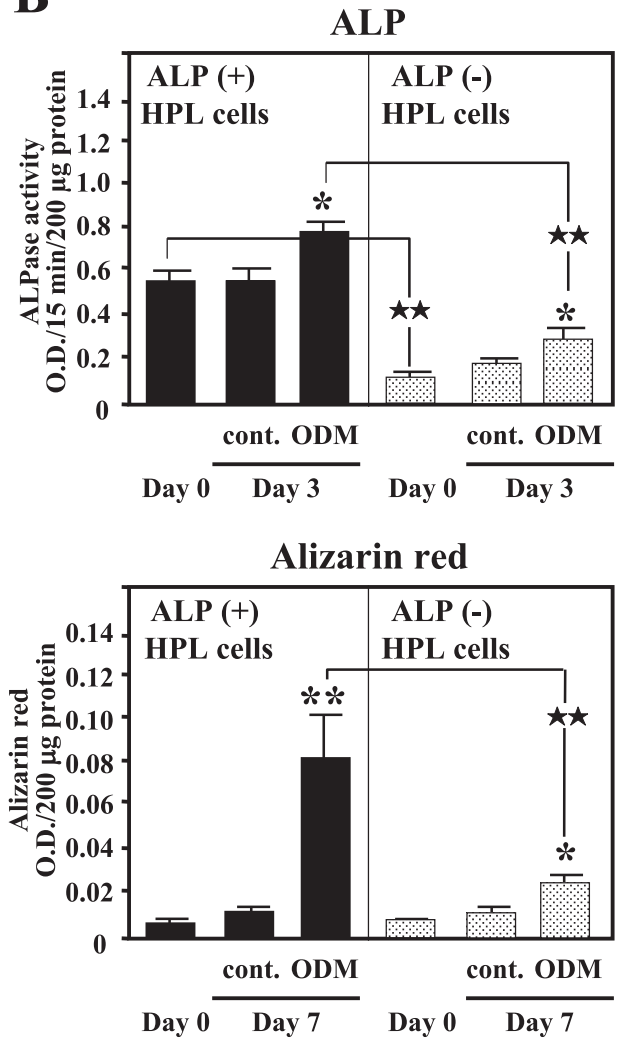

Fig. 3 Osteogenic potential in ALP $(+)$ HPL cells and ALP $(-)$ HPL cells. ALP $(+)$ HPL cells and ALP (-) HPL cells were respectively cultured for 3 days in MSCGM until confluence and further cultured with Osteogenic differentiation medium (ODM) or control medium (MSCGM) for 3 and 7 days. Following each culture, cells were used for staining for ALP activity and alizarin red staining (mineralized nodule formation) (A), and ALP activity and amounts of alizarin red were measured (B), as described in MATERIALS AND Methods. C: Expression of bone-specific genes in both subsets cultured with ODM or control medium for 7 days. Total RNA was extracted from cells and subjected to RT-RCR analysis for gene expression of ALP, osterix and osteopontin. The graph demonstrates the ratio of each bonespecific gene to GAPDH in ALP(-) HPL cells (dotted bar) as a multiple of the ratio of those in ALP (+) HPL cells (closed bar). A, C: Each photograph is representative of the result from one of three separate experiments in $\operatorname{ALP}(+)$ HPL-1 cells and ALP (-) HPL-1 cells. Similar results were obtained with both subsets isolated from each of HPL-2 cells and HPL-3 cells. B, C: Each value in graphs is shown as the mean \pm S.D. of 3 separate experiments, for each subset isolated from each of the 3 populations of HPL cells (HPL-1, -2 and -3 cells) $(n=9)$. Differences from the value for control cells or ALP (+) HPL cells were considered to be significant at $\mathrm{p}<0.05 \quad(*)$ and $\mathrm{p}<0.01 \quad(* *)$ or $\mathrm{p}<0.01(\star \star)$, respectively. 
$\mathbf{A}$
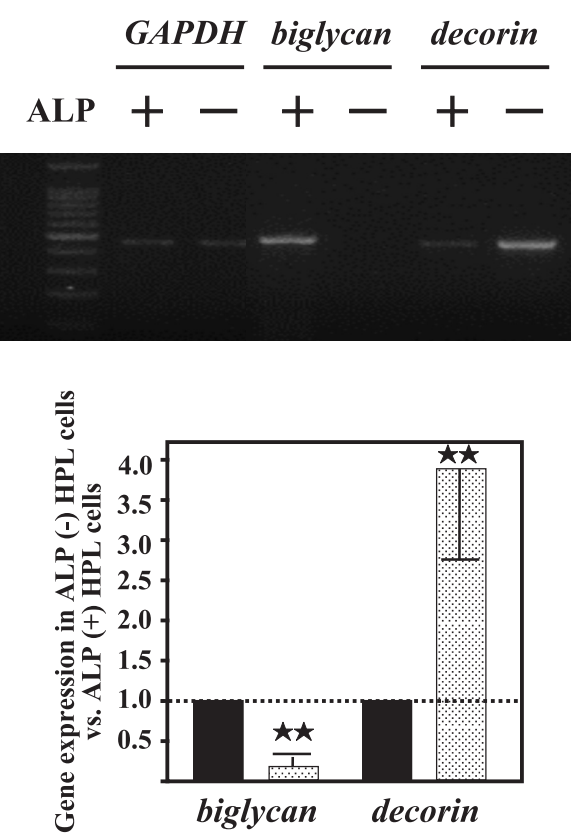

B

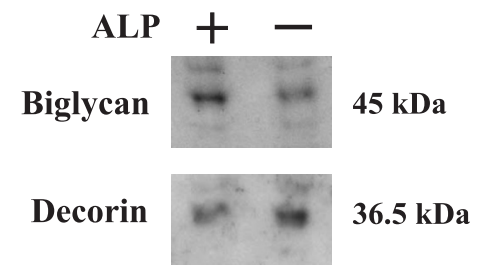

Fig. 4 Expression of biglycan and decorin in $\operatorname{ALP}(+)$ HPL cells and ALP $(-)$ HPL cells. ALP $(+)$ HPL cells and ALP $(-)$ HPL cells were respectively cultured for 3 days in MSCGM until confluence. Following each treatment, the expression of biglycan and decorin at mRNA (A) and protein (B) levels was determined using RT-PCR and Western blotting, respectively. A, B: Each photograph is representative of the result from one of three separate experiments in ALP(+) HPL-3 cells and ALP (-) HPL-3 cells. Similar results were obtained with both subsets isolated from each of HPL-4 cells and HPL-5 cells. A: The graph demonstrates the ratio of each gene to GAPDH in ALP (-) HPL cells (dotted bar) as a multiple of the ratio of those in $\operatorname{ALP}(+)$ HPL cells (closed bar). Each value represents the mean \pm S.D. of 3 separate experiments, for each subset isolated from each of the 3 populations of HPL cells (HPL-3, -4 and -5 cells) $(n=9)$. Differences from the value for ALP $(+)$ HPL cells were considered to be significant at $\mathrm{p}<0.01(\star \star)$.
A

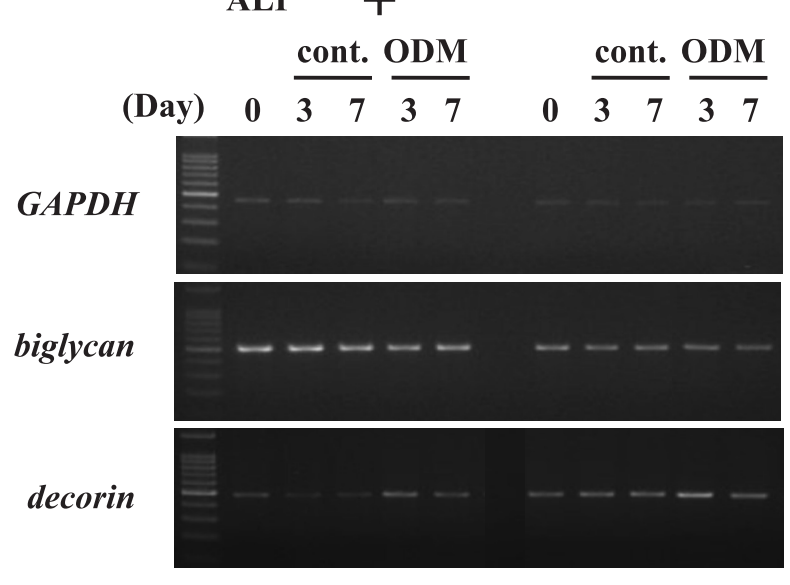

B

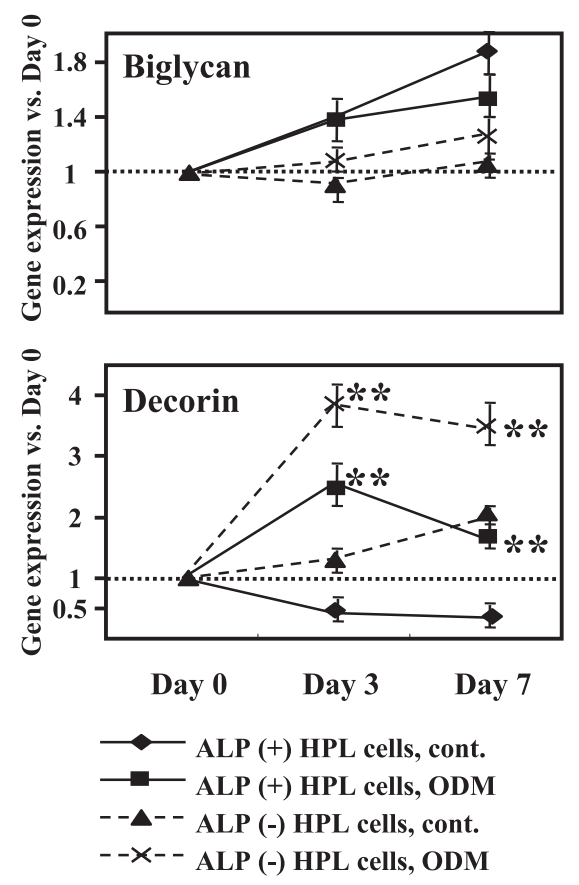

Fig. 5 Changes of gene expression of biglycan and decorin in ALP $(+)$ HPL cells and $\operatorname{ALP}(-)$ HPL cells cultured with ODM. ALP $(+)$ HPL cells and ALP $(-)$ HPL cells at confluence were respectively cultured with ODM or control medium for 3 and 7 days. Following each treatment, the expression of biglycan and decorin mRNA was determined using RT-PCR. A: Each photograph is representative of the result from one of three separate experiments in $\operatorname{ALP}(+)$ HPL-3 cells and ALP (-) HPL-3 cells. Similar results were obtained with both subsets isolated from each of HPL- 4 cells and HPL- 5 cells. B: The graph demonstrates the ratio of each gene to GAPDH on day 3 or day 7 as a multiple of the ratio of those on day 0 . Each value represents the means \pm S.D. of 3 separate experiments, for each subset isolated from each of the 3 populations of HPL cells (HPL-3, -4 and -5 cells) ( $n=$ 9). Differences from the value for control cells were considered to be significant at $\mathrm{p}<0.01(* *)$. 
A

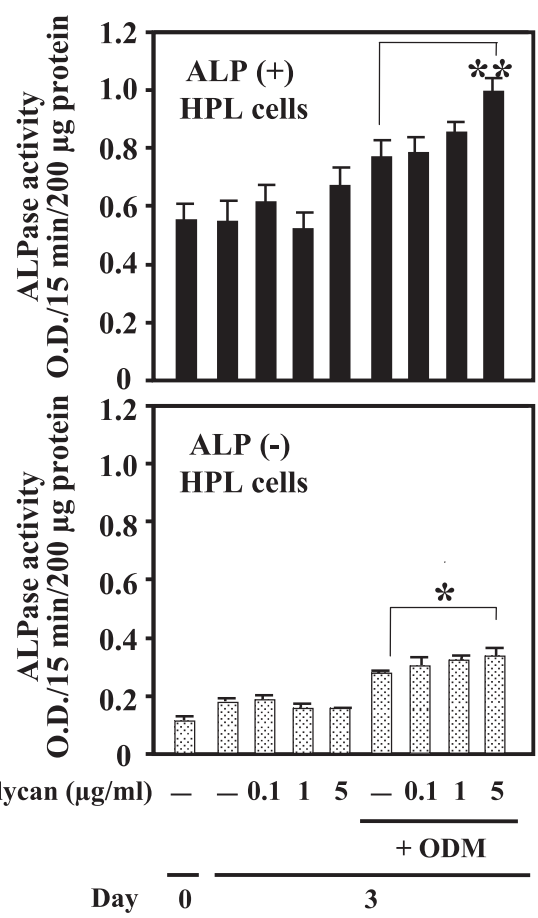

B
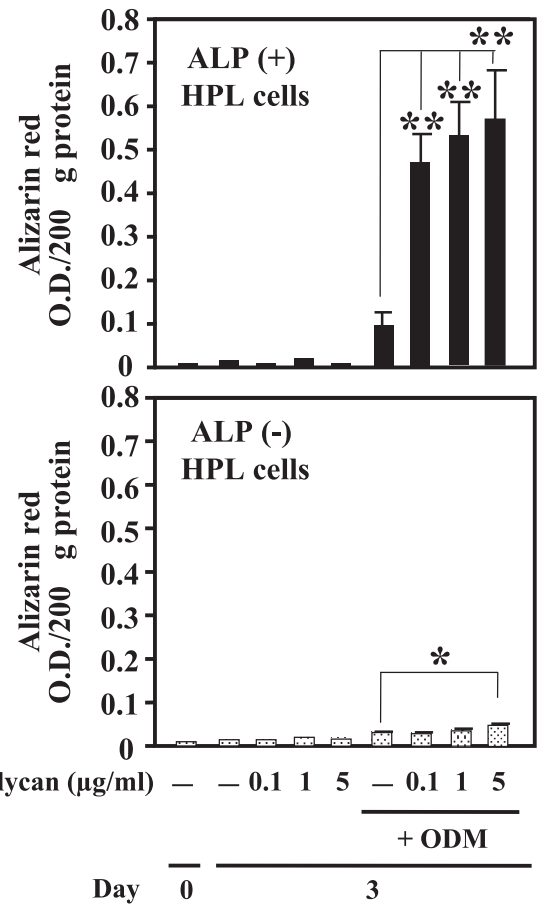

Fig. 6 Effects of biglycan on osteoblastic differentiation in ALP $(+)$ HPL cells and ALP $(-)$ HPL cells. ALP $(+)$ HPL cells and ALP $(-)$ HPL cells at confluence were respectively cultured with ODM or control medium in the presence or absence of recombinant biglycan $(0.1,1$ and $5 \mu \mathrm{g} / \mathrm{ml})$ for 3 and 7 days. Following each culture, ALP activity (A) and amounts of alizarin red (B) were measured. Each value is shown as the means \pm S.D. of 3 separate experiments, for each subset isolated from each of the 3 populations of HPL cells (HPL-3, -4 and -5 cells) $(n=9)$. Differences from the value for control cells were considered to be significant at $\mathrm{p}<0.05{ }^{(*)}$ and $\left.\mathrm{p}<0.01{ }^{(* *}\right)$.

\section{Biglycan が骨芽細胞様分化に及ぼす作用}

HPL-3，-4，-5 cells から分取した両細胞集団を MSCGM でコンフルエントに達するまで培養後, さらに 精製ヒト Biglycan の存在あるいは非存在下に扔いて, ODM あるいはコントロール培地で $3 ， 7$ 日間培養した。 その結果, 両細胞集団共, ODM で 3 日間培養した細胞で 認められる ALP 活性の上昇と 7 日間培養した細胞で認 められる細胞層中の Alizarin red 量の増加は, 精製ヒト Biglycan の同時刺激により [Biglycan 濃度 : ALP $(+)$ cells では ALP 活性は $5 \mu \mathrm{g} / \mathrm{ml}$ で, Alizarin red 量は 0.1 $5 \mu \mathrm{g} / \mathrm{ml}$ で, ALP $(-)$ cells では ALP 活性, Alizarin red 量共に $5 \mu \mathrm{g} / \mathrm{ml}$ で] 有意に促進された (Figure 6A，6B)。また，この Biglycan の促進作用は $\operatorname{ALP}(+)$ cells で顕著であった (Fig. 6A, 6B).

\section{考察}

歯根膜組織中には，セメント質や歯槽骨などの硬組織 を形成する骨芽細胞様の細胞と，腱や靯帯と類似した構 造・機能を有する歯根膜線維を形成する線維芽細胞様の
細胞が存在していると考えられているが，これらを識 別・分取することが可能な特徵的なマーカー分子は明確 ではない。一方 ALP は, 硬組織の形成や石灰化に関与す

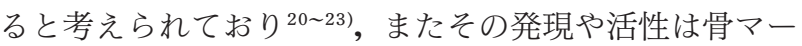
カーとして使用されている.さらに，ALPには可溶型と 膜結合型が存在するが，その活性は主として膜結合型に 依存している ${ }^{24)}$.そこで本研究では，このALP を指標と して,2 つの細胞集団 $[\operatorname{ALP}(+)$ HPL cells と ALP $(-)$ HPL cells] を分取し，その特徴を比較した。

過去の報告8,9) では, ALP 陽性と陰性の HPL cells の 分取を磁気ビーズ法で行っている。これまで我及が行っ た予備実験の結果から，本研究と同一の抗ヒ卜ALP 抗 体を使用し，HPL cells から磁気ビーズ法で ALP 陽性 細胞を分取したのち, FACS で ALP 陽性細胞率を調べ ると，1 回の処理では $90 \%$ ALP 陰性の細胞が 10\%混 入していること，また同様の操作を 3 回繰り返し行って も ALP 陽性細胞率が 100\%近い細胞集団を分取できな いことを確認している (data not shown)。 また, 予備 実験において，分取時の HPL cells における ALP 陽性 
細胞率は，培養条件や骨芽細胞様分化の程度により異な つていた。すなわち，MSCGM で培養した細胞よりも MEM $\alpha$ で培養した細胞で, また, 対数増殖期の細胞よ りもコンフルエント後の骨芽細胞様の表現型が発現した 細胞で, ALP 陽性細胞率が高いことを明らかにしている (data not shown)。そこで本研究では, より正確に ALP 陰性細胞と ALP 陽性細胞を分取するために, MEM $\alpha$ で, コンフルエントに達したのちさらに 3 日間培養した HPL cells（ALP 活性が最大值を示す）から FACS で, 蛍光強度が著しく強い ALP 陽性の細胞集団 $[\operatorname{ALP}(+)$ HPL cells] (平均 6.28\%) と蛍光強度が著しく弱い ALP 陰性の細胞集団 [ALP (一) HPL cells]（平均 5.55\%) を 分取した。また, 分取した ALP $(+)$ HPL cells 中の ALP 陽性細胞率は $99.9 \%$ 以上, 一方, ALP (-) HPL cells 中 の ALP 陽性細胞率は $0.1 \%$ 以下であった。したがって本 研究では，より純度の高いALP 陽性と陰性の細胞集団 を回収し，それぞれの細胞集団の性質を解析することが できたと考えている。実際，コンフルエントに達した ALP (+) HPL cells は ALP (-) HPL cells と比較し て, 明らかに高い ALP 活性を示したが，これら二つの細 胞集団におけるALP 活性值は，分取後 2 代継代した細 胞（4 代目）でも変化しなかった（data not shown）。

本研究において, ALP (-) HPL cells は ALP (+) HPL cellsよりも増殖能が高かった。一方，両細胞を ODM で培養すると, $\operatorname{ALP}(+)$ HPL cells は ALP $(-)$ HPL cells と比較して, より明確な骨芽細胞様分化の促 進 $[$ ALP 活性の上昇, 石灰化の誘導, 骨マーカー遺伝子 (ALP, osterix, osteopntin) の発現促進] が認められた. この結果は，過去の報告8,9) の結果を支持している。し たがって，ALP $(+)$ HPL cells は骨芽細胞様の細胞集 団であり，一方，ALP (一) HPL cells は骨芽細胞様の 分化能が乏しい線維芽細胞様の細胞集団であると考えら れる。

SLRP に属する Biglycan と Decorin は，皮膚，半月 板，関節軟骨，腱，靱帯，歯周組織，骨などの組織・臓 器や歯周組織由来の線維芽細胞での発現が確認されて いる10 12,25 30). 本研究において, $\operatorname{ALP}(+)$ HPL cells と ALP (-) HPL cells もこれらの分子を遺伝子レベルお よびタンパク質レベルで発現していたが，興味深いこと に, Decorin の発現は ALP $(-)$ HPL cells で強く, 一方 Biglycanの発現は ALP $(+)$ HPL cells で強かった。

Biglycan と Decorin は I, II, III 型のコラーゲンと結 合し ${ }^{31)}$ ，コラーゲン線維間の距離や他の ECM の産生・機 能に影響を及ぼしている ${ }^{25,32)}$.また, Decorin はコラーゲ ン線維の形成や皮膚，带における恒常性維持に関与す ると報告されている ${ }^{33,34)}$. 一方，これらの SLRP はヒ卜
の骨芽細胞におけるコラーゲン合成を変化させないと報 告されている ${ }^{31)}$. したがって, 歯根膜組織中に存在する ALP 陰性の線維芽細胞様細胞とALP 陽性の骨芽細胞 様細胞が産生するこれらの SLRP (特に Decorin) は, 歯 根膜線維のリモデリングを制御していると考えられる。

これら二つの SLRP は in vitro において, ヒト骨芽細 胞のコラーゲンへの付着と増殖を促進する ${ }^{31,35)}$. また， Biglycanのノックアウトマウスでは, 骨量の減少により 骨粗鬆症様の表現型を示し ${ }^{36)}$ ，また加齢に伴う骨粗鬆症 を悪化させる ${ }^{37)}$. 一方, Decorin のノックアウトマウスで は，このような骨粗鬆症様の表現型は認められない ${ }^{38)}$. しかし, Decorin と Biglycanのダブルノックアウトマ ウスでは, Biglycanのみをノックアウトした場合と比 較して，より顕著な骨形成の抑制が認められたことか $ら^{39 \sim 41)}$, Decorin と Biglycan は相乗的に骨形成を促進 している可能性がある。また, in vitroにおいて, BMP-4 が誘導する骨芽細胞分化には Biglycan が必須であり ${ }^{42)}$, Biglycanの遺伝子を過剰発現させた骨芽細胞では分化 と基質の石灰化が促進され, 逆にこの遺伝子の発現を抑 制するとこれらが抑制されることが明らかにされてい $る^{14)}$. 一方, Mochida ら ${ }^{15)}$ は, Decorin を過剩発現させ た骨芽細胞では石灰化の開始が遅延し，逆に発現を抑制 すると石灰化が促進するが，この遺伝子の発現の有無は 骨芽細胞の増殖や分化には影響しないと報告している。 したがって, Biglycan は骨形成や骨芽細胞の増殖・分 化・活性・石灰化を促進的に制御するのに対し，Decorin は骨形成や骨芽細胞の増殖・分化に影響せず，むしろ石 灰化を抑制的に制御している可能性がある。本研究にお いても, 精製ヒト Biglycanは, 特に ALP $(+)$ HPL cells において，ODM が誘導する骨芽細胞様分化を有意に立 進した。したがって，ALP(+) HPL cells で比較的強く 発現している Biglycan は，この細胞集団における骨芽 細胞様分化を促進的に制御していると考えられる。一方, ALP (一) HPL cells で比較的強く発現している Decorin は，この細胞集団に打ける石灰化を恒常的に抑制して いる可能性がある。また, ALP $(+)$ HPL cells と ALP （一）HPL cells を ODM で培養して骨芽細胞様分化を 誘導すると, Biglycanの発現は変化しなかったが, Decorinの発現は促進されたことから, Decorin は骨芽 細胞様分化の誘導過程で発現が増加し, これらの細胞集 団における石灰化の誘導を抑制的に制御している可能性 がある。

Decorin と Biglycan は TGF- $\beta$ や Bone morphogenetic protein-2/4 (BMP-2/4) と結合し，これらの成 長因子の活性, すなわち, 骨芽細胞の増殖, ECM への 結合，コラーゲンや他の ECM の産生誘導，走化性に及 
ぼす TGF- $\beta$ の作用や，骨形成，骨芽細胞の分化・石死 化に及ぼす BMP-2/4の作用を調節している ${ }^{35,41 \sim 50)}$ 。一 方, HPL cells もこれらの成長因子を産生して, 自らの 機能を制御している。したがって，これら 2 つの SLRP は直接的あるいはこれと結合する TGF- $\beta$ や BMP-2/4 の作用を調節することにより間接的に, $\operatorname{ALP}(+) \mathrm{HPL}$ cells と ALP $(-)$ HPL cells の機能に関与していると考 えられる。

本研究では, HPL cells から FACS で蛍光強度が著し く強い ALP 陽性の細胞集団 [ALP $(+)$ HPL cells] と 蛍光強度が著しく弱い ALP 陰性の細胞集団 $[\operatorname{ALP}(-)$ HPL cells] を分取し, これら二つの細胞集団の特徵, 特 に細胞増殖能，骨芽細胞様分化能および Biglycan と Decorinの発現を比較検討した. その結果, $\operatorname{ALP}(+)$ HPL cells は骨芽細胞様の細胞集団であり，一方，ALP (一) HPL cells は細胞増殖能が高く, 骨芽細胞様の分化 能がそしい線維芽細胞様の細胞集団であった。Biglycan は ALP $(+)$ HPL cellsで, Decorin ALP $(-)$ HPL cells でより強く発現していた.また, 精製ヒト Biglycan は, 特にALP $(+)$ HPL cells において, ODM が誘導す る骨芽細胞様分化を有意に元進した。さらに，両細胞集 団を ODM で培養すると, Decorinの発現は促進された が, Biglycanの発現は変化しなかった。したがって, Biglycan は特にALP $(+)$ HPL cellsにおける骨芽細胞 様分化を促進的に制御しており，一方 Decorin は特に ALP (一) HPL cells における石灰化を恒常的に抑制し ている可能性がある。本研究の結果は，歯根膜組織の再 生や恒常性の維持に果たすALP 陽性と陰性の歯根膜細 胞の役割の違いを, これら二つの SLRP の発現パターン と機能から明確にしたと考える。

\section{謝辞}

本研究は, 昭和大学歯学研究科ハイテクリサーチセン ター研究開発プロジェクト補助金, 昭和大学共同研究補 助金，ならびに科学研究費補助金（課題番号 18791603, 18592269，19791622）の支援を受けて遂行した。また， FACS 解析と細胞分取は慶応義塾大学医学部生理学教 室，松崎有未博士の協力を得て遂行した。

\section{文献}

1) Seo BM, Miura M, Gronthos S, Bartold PM, Batouli S, Brahim J, Young M, Robey PG, Wang C-U, Shi S: Investigation of multipotent postnatal stem cells from human periodontal ligament. Lancet, 364: 149-155, 2004

2) Nyman S, Gottolow J, Karring T, Lindhe J: The regenerative potential of the periodontal liga- ment. An experimental study in the monkey. J Clin Periodontol, 9: 157-265, 1982

3) Isaka J, Ohazama A, Kobayashi M, Nagashima C, Takiguchi T, Kawasaki H, Tachikawa T, Hasegawa K: Participation of periodontal ligament cells with regeneration of alveolar bone. J Periodontol, 72: 314-323, 2001

4) Somerman MJ, Archer SY, Imm GR, Foster RA: A comparative study of human periodontal ligament cells and gingival fibroblasts in vitro. J Dent Res, 67: 66-70, 1988

5) Cho MI, Matsuda N, Lin WL, Moshier A, Ramakrishnan PR: In vitro formation of mineralized nodules by periodontal ligament cells from the rat. Calcif Tissue Int, 50: 459-467, 1992

6) Arceo N, Sauk JJ, Moehring J, Foster RA, Somerman MJ: Human periodontal cells initiate mineral-like nodules in vitro. J Periodontol, 62: 499-503, 1991

7) Nojima N, Kobayashi M, Shionome M, Takahashi N, Suda T, Hasegawa K: Fibroblastic cells derived from bovine periodontal ligaments have the phenotypes of osteoblasts. J Periodont Res, 25: 179-185, 1990

8）奥津朋彦, 小林 誠, 小出容子, 高田貴虎, 滝口 尚, 山本松男：培養歯根膜細胞中における各種間葉系前 駆細胞の存在確認。昭歯誌，27: 165-172, 2007

9) Murakami Y, Kojima T, Nagasawa T, Kobayashi H, Ishikawa I: Novel isolation of alkaline phosphatase-positive subpopulation from periodontal ligament fibroblasts. J Periodontol, 74: 780-786, 2003

10) Vogel KG, Ordög A, Pogány G, Oláh J: Proteoglycans in the compressed region of human tibialis posterior tendon and in ligaments. J Orthop Res, 11: 68-77, 1993

11) Häkkinen L, Oksala O, Salo T, Rahemtulla F, Larjava H: Immunohistochemical localization of proteoglycans in human periodontium. J Histochem Cytochem, 41: 1689-1699, 1993

12) Qian H, Xiao Y, Bartold PM: Immunohistochemical localization and expression of fibromodulin in adult rat periodontium and inflamed human gingiva. Oral Dis, 10: 233-239, 2004

13) Waddington RJ, Roberts HC, Sugars RV, Schönherr E: Differential roles for small leucine-rich proteoglycans in bone formation. Eur cell Mater, 6: 12-21, 2003

14) Parisuthiman D, Mochida Y, Duarte WR, Yamauchi M: Biglycan modulates osteoblast differentiation and matrix mineralization. J Bone Miner Res, 20: 1878-1886, 2005

15) Mochida Y, Duarte WR, Tanzawa H, Paschalis EP, Yamauchi M: Decorin modulates matrix mineralization in vitro. Biochem Biophys Res Commun, 305: 6-9, 2003

16) Bradford MM: A rapid and sensitive method for 
the quantitation of microgram quantities of protein utilizing the principle of protein-dye binding. Anal Biochem, 72: 248-254, 1976

17) Fujii S, Maeda H, Wada N, Kano Y, Akamine A: Establishing and characterizing human periodontal ligament fibroblasts immortalized by SV40 T-antigen and hTERT gene transfer. Cell Tissue Res, 324: 117-125, 2006

18) Norris RA, Damon B, Mironov V, Kasyanov V, Ramamurthi A, Moreno-Rodriguez R, Trusk T, Potts JD, Goodwin RL, Davis J, Hoffman S, Wen X, Sugi Y, Kern CB, Mjaatvedt CH, Turner DK, Oka T, Conway SJ, Molkentin JD, Forgacs G, Markwald RR: Periostin regulates collagen fibrillogenesis and the biomechanical properties of connective tissues. J Cell Biochem, 101: 695-711, 2007

19) Chen AL, Fang C, Liu C, Leslie MP, Chang E, Di Cesare PE: Expression of bone morphogenetic proteins, receptors, and tissue inhibitors in human fetal, adult, and osteoarthritic articular cartilage. J Orthop Res, 22: 1188-1192, 2004

20) Genge BR, Sauer GR, Wu LNY, Mclean FM, Wuthier RE: Correlation between loss of alkaline phosphatase activity and accumulation of calcium during matrix vesicle mediated mineralization. J Biol Chem, 263: 18513-18519, 1988

21) Beertsen $W$, Van den Bos $T$ : Calcification of dental collagen by cultured rabbit periosteum: The role of alkaline phosphatase. Matrix, 9: 159171, 1989

22) Beertsen W, Van den Bos T: Alkaline phosphatase induces the deposition of calcified layers in relation to dentine: An in vitro study to mimic the formation of afibrillar acellular cementum. J Dent Res, 70: 176-181, 1991

23) Beertsen W, Van den Bos T: Alkaline phosphatase induces the mineralization of sheets of collagen implants subcutaneously in the rat. J Clin Invest, 89: 1974-1980, 1992

24) Togari A, Arakawa S, Arai M, Matsumoto S: Inhibition of in vitro mineralization in osteoblastic cells and in mouse tooth germ by phosphatidylinositol-specific phospholipase C. Biochem Pharmacol, 46: 1668-1670, 1993

25) Whinna HC, Choi HU, Rosenberg LC, Church FC: Interaction of heparin cofactor II with biglycan and decorin. J Biol Chem, 268: 3920-3924, 1993

26) Cheng H, Caterson B, Yamauchi M: Identification and immunolocalization of chondroitin surfate proteoglycans in tooth cementum. Connective Tissue Res, 40: 37-47, 1999

27) Oksala O, Salo T, Tammi R, Häkkinen L, Jakanen $\mathrm{M}$, Inki P, Larjava $\mathrm{H}$ : Expression of proteoglycans and hyaluronan during wound healing. J Histochem Cytochem, 43: 125-135, 1995

28) Fisher LW, Termine JD, Dejter SW Jr., Whitson
SW, Yanagishita M, Kimura JH, Hascall VC, Kleinman HK, Hassel JR, Nilsson B: Proteoglycans of developing bone. J Biol Chem, 258: 6588-6597, 1983

29) Bianco P, Fisher LW, Young MF, Termine JD, Robey PG: Expression and localization of the two small proteoglycans biglycan and decorin in developing human skeletal and non-skeletal tissues. J Histochem Cytochem, 38: 1549-1563, 1990

30) Larjava H, Häkkinen L, Rahemetulla F: A biochemical analysis of periodontal tissue proteoglycans. Biochem J, 284: 267-274, 1992

31) Douglas T, Hempel U, Mietrach C, Viola M, Vigetti D, Heinemann S, Bierbaum S, Scharnweber D, Worch H: Influence of collagen-fibrilbased coatings containing decorin and biglycan on osteoblast behavior. J Biomed Mater Res, 84A: 805-816, 2008

32) Schönherr E, Witsch-Prehm P, Harrach B, Robenek H, Rauterberg J, Kresse H: Interaction of biglycan with type I collagen. J Biol Chem, 270: 2776-2783, 1995

33) Reed CC, Iozzo RV: The role of decorin in collagen fibrillogenesis and skin homeostasis. Glycoconj J, 19: 249-255, 2003

34) Vogel KG, Paulsson M, Heinegard D: Specific inhibition of type I and type II collagen fibrillogenesis by the small proteoglycan of tendon. Biochem J, 223: 587-597, 1984

35) Bierbaum S, Douglas T, Hanke T, Scharnweber D, Tippelt S, Monsees TK, Funk RH, Worch H: Collageneous matrix coating on titanium implants modified with decorin and biglycan sulfate: Characterization and influence on osteoblastic cells. J Biomed Mater Res, 77A: 551-562, 2006

36) Chen XD, Shi S, Xu T, Robey PG, Young MF: Age-related osteoporosis in biglycan-deficient mice is related to defects in bone marrow stromal cells. J Bone Miner Res, 17: 331-340, 2002

37) $\mathrm{Xu} \mathrm{T}$, Bianco P, Fisher LW, Longenecker G, Smith E, Goldstain S, Bonadio J, Boskey A, Heegard AM, Sommer B, Satomura K, Dominguez P, Zhao C, Kulkarni AB, Robey PG, Young MF: Targeted disruption of the biglycan gene leads to an osteoporosis-like phenotype in mice. Nat Genet, 20: 78-82, 1998

38) Danielson KG, Baribault H, Holmes DF, Graham $\mathrm{H}$, Kadler KE, Iozzo RV: Targeted disruption of decorin leads to abnormal collagen fibril morphology and skin fragility. J Cell Biol, 136: 729-743, 1997

39) Ameye L, Young MF: Mice deficient in small leucine-rich proteoglycans: Novel in vivo models for osteoporosis, osteoarthritis, Ehlers-Danlos syndrome, muscular dystrophy, and corneal disease. Glycobiology, 12: 107 R-116 R, 2002

40) Corsi A, Xu TXuXD, Chen A, Boyde J, Liang J, 
Mankani M, Sommer B, Iozzo RV, Eichstetter I, Robey PG, Bianco P, Young MF: Phenotypic effects of biglycan deficiency are linked to collagen fibril abnormalities, are synergized by decorin deficiency, and mimic Ehlers-Danlos-like changes in bone and other connective tissues. J Bone Miner Res, 17: 1180-1189, 2002

41) Yanming Bi, Stuelten $\mathrm{CH}$, Kilts $\mathrm{T}$, Wadhwa $\mathrm{S}$, Iozzo RV, Robey PG, Chen X-D, Young MF: Extracellular matrix proteoglycans control the fate of bone marrow stromal cells. J Biol Chem, 280: 30481-30489, 2005

42) Chen XD, Fisher LW, Robey PG, Young MF: The small leucine-rich proteoglycan biglycan modulates BMP-induced osteoblast differentiation. Faseb J, 18: 948-958, 2004

43) Gutierrez J, Osses N, Brandan E: Changes in secreted and cell associated proteoglycan sunthesis during conversion of myoblasts to osteoblasts in response to bone morphogenetic protein-2: Role of decorin in cell response to BMP-2. J Cell Physiol, 206: 58-67, 2006

44) Mundy GR: Regulation of bone formation by bone morphogenetic proteins and other growth factors. Clin Orthop Relat Res, 324: 24-28, 1996

45) Hildebrand A, Romaris M, Rasmussen LM, Heinegard D, Twardzik DR, Border WA, Ruos- lahti E: Interaction of the small interstitial proteoglycans biglycan, decorin and fibromodulin with transforming growth factor beta. Biochem J, 302 (Pt 2): 527-534, 1994

46) Hausser H, Groning A, Hasilik A, Schonherr E, Kresse H: Selective inactivity of TGF- $\beta /$ decorin complexes. FEBS Lett, 353: 243-245, 1994

47) Takeuchi $Y$, Kodama Y, Matsumoto T: Bone matrix decorin binds transforming growth factor$\beta$ and enhances its bioactivity. J Biol Chem, 269: 32634-32638, 1994

48) Moreno M, Munoz R, Aroca F, Labarca M, Brandan E, Larrain J: Biglycan is a new extracellular component of the chordin-BMP4 signaling pathway. EMBO J, 24: 1397-1405, 2005

49) Zhu Y, Oganesian A, Keene DR, Sandell LJ: Type IIA procollagen containing the cysteine-rich amino propeptide is deposited in the extracellular matrix of prechondrogenic tissue and binds to TGF-beta and BMP-2. J Cell Biol, 144: 1069-1080, 1999

50) Andrades JA, Santamaria JA, Wu LT, Hall FI, Nimni ME, Becerra J: Production a recombinant human basic fibroblast growth fator with a collagen binding domain. Protoplasma, 218: 95-103, 2001 


\title{
Characterization of Alkaline Phosphatase-Positive and -Negative Cells Isolated from Human Periodontal Ligament Cells
}

\author{
Ayuko Tsurumi, Makoto KoBAyASHI, Ryo-ichiro Murayama, \\ Michihiko Usui, Yoko KoIDE and Matsuo Yamamoto \\ Department of Periodontology, Showa University School of Dentistry \\ 2-1-1 Kitasenzoku, Ohta-ku, Tokyo, 145-8515 Japan
}

(Received October 30, 2008; Accepted for publication December 24, 2008)

\begin{abstract}
Periodontal ligament (PL) contains fibroblastic cells, which may participate in formation and maintenance of PL fibers, and osteoblastic cells with a potential to generate alveolar bone and cementum, however, the specific markers for recognition and isolation of each cell type have not been clarified. The purpose of this study was to isolate alkaline phosphatase (ALP)-positive and -negative subpopulations from heterogeneous human PL (HPL) cells using flowcytometry and to identify functional difference between the 2 subsets in terms of mitogenic activity, osteogenic potential and expression of decorin as well as biglycan. We separately isolated ALP-positive and -negative cells from each of 5 populations of HPL cells. The mitogenic activity of ALP-negative cells was higher than that of ALP-positive cells, while ALP-positive cells showed remarkably stronger osteogenic potential, such as induction of ALP activity, bone-specific gene expression and mineralization by culturing with osteogenic differentiation medium (ODM), than ALP-negative cells. In ALP-positive cells, expression level of biglycan was higher, but decorin expression was weaker, as compared with ALP-negative cells. The ODM-induced osteoblastic differentiation was significantly enhanced by adding recombinant biglycan exogenously in ALP-positive cells. When the 2 subpopulations were cultured with ODM, gene expression of decorin was increased, whereas biglycan expression had no change. These results suggest that ALP-positive HPL cells have osteoblast-like phenotype, while ALP-negative HPL cells are fibroblastic cell population with weak osteogenic potential. Further, biglycan may positively regulate osteoblastic differentiation in ALP-positive HPL cells, while decorin, whose expression is increased by osteogenic induction, may negatively regulate mineralization in both subpopulations.
\end{abstract}

Key words: human periodontal ligament cells, alkaline phosphatase, osteoblastic differentiation, decorin, biglycan 